\title{
The Inter-Relationship of Periostin, TGF $\beta$, and BMP in Heart Valve Development and Valvular Heart Diseases
}

\author{
Simon J. Conway ${ }^{1}$, Thomas Doetschman ${ }^{2,3}$, and Mohamad Azhar ${ }^{2,3, *}$ \\ ${ }^{1}$ Riley Heart Research Center, Wells Center for Pediatric Research, Indiana University \\ School of Medicine, Indianapolis; ${ }^{2}$ BIO5 Institute, University of Arizona, Tucson; \\ ${ }^{3}$ Department of Cellular and Molecular Medicine, University of Arizona, Tucson \\ E-mail: azharm@email.arizona.edu
}

Received August 23, 2009; Revised June 28, 2011; Accepted July 4, 2011; Published July 28, 2011

Recent studies have suggested an important role for periostin and transforming growth factor beta (TGF $\beta$ ) and bone morphogenetic protein (BMP) ligands in heart valve formation and valvular heart diseases. The function of these molecules in cardiovascular development has previously been individually reviewed, but their association has not been thoroughly examined. Here, we summarize the current understanding of the association between periostin and TGF $\beta$ and BMP ligands, and discuss the implications of this association in the context of the role of these molecules in heart valve development and valvular homeostasis. Information about hierarchal connections between periostin and TGF $\beta$ and BMP ligands in valvulogenesis will increase our understanding of the pathogenesis, progression, and medical treatment of human valve diseases.

KEYWORDS: periostin, transforming growth factor beta, TGF $\beta$, bone morphogenetic protein, BMP, heart development, heart valves, Marfan syndrome

\section{INTRODUCTION}

About one-fourth of patients with congenital heart disease, which affects approximately $5 \%$ of live births, have structural anomalies of one or more heart valves[1,2]. Isolated bicuspid aortic valve and congenital polyvalvular disease represent major congenital cardiac valve malformations[3,4,5]. From a developmental point of view, the bicuspid aortic valve is usually not stenotic, but it may develop secondary stenosis or calcification. Bicuspid aortic valves with normal structure can be diagnosed under congenital polyvalvular disease. In congenital polyvalvular disease, two or more of the valves are congenitally abnormal (e.g., ventricular septal defect, tetralogy of Fallot), and show valve thickening and disrupted valve architecture. Congenital polyvalvular disease is typically seen in patients with trisomy 18 , Noonan syndrome, and Marfan syndrome. In pediatric patients, $70-85 \%$ of stenotic aortic valves are bicuspid and at least $50 \%$ of adults with aortic stenosis have bicuspid aortic valves. If it is accepted that the incidence of bicuspid aortic valve is $1-2 \%$ and that serious complications occur in at least one-third of the cases, this condition may be responsible for more deaths and morbidity than the combined effects of all other congenital heart defects[6]. Interestingly, there is a marked distinction in the molecular profile 
between pediatric (i.e., stenotic) and adult (i.e., calcified) diseased aortic valves[7]. It has also been noted that aortic valves, and rarely tricuspid valves, develop calcification and that the pathology of diseased mitral valves includes myxomatous degeneration, but not calcification[8]. Myxomatous mitral valves are characterized by floppy leaflets and elongated or ruptured chordae tendineae, which have profoundly weakened material behavior compared to normal valve tissues[9]. Mature normal human valves have a trilaminar tissue organization of the extracellular matrix (ECM): elastin-rich atrialis (mitral/tricuspid valves) or ventricularis (semilunar valves), glycosaminoglycan (GAG)-rich spongiosa, and collagencontaining fibrosa[10]. Histologic findings of myxomatous valvular disease include highly fragmented collagen within the valve fibrosa and excess accumulation of GAGs, which causes billowing of the valve leaflets, with or without prolapse and regurgitation of mitral or aortic valves[11,12,13]. Regardless of the classification of valve disease, the valve thickening is often an early and major clinical complication of cardiac valve dysfunction in neonatal/infantile and adult patients with inherited (bicuspid aortic valve or congenital polyvalvular disease) or acquired conditions, including Marfan syndrome-like disorders, Noonan syndrome, isolated non-syndromic X-linked myxomatous valvular dystrophy, rheumatic arthritis, and anti-Parkinson's disease drug-induced (dopamine agonists, i.e., pergolide and cabergoline) valvular disease[14,15,16,17,18,19,20]. At the molecular and genetic levels, periostin and transforming growth factor beta (TGF $\beta$ ) and bone morphogenetic protein (BMP) ligands have emerged as important players in heart valve formation and remodeling, and valvular heart diseases in mammals[21,22,23,24,25] (Fig. 1). In this review, we summarize the important current information about the individual activities of these molecules, and highlight their association and potential role in valve development and disease.

\section{FORMATION, REMODELING, AND MATURATION OF HEART VALVES}

Cardiovascular development is considered a complex interplay of many cell-cell and cell-matrix interactions[26,27]. It is thought that disruption of in utero developmental processes in heart valve formation predispose patients to progressive postnatal valvular disease[22,28]. The process of valvulogenesis begins with an epithelial mesenchymal transition (EMT) (embryonic day [E] 9.5 to E10.5 in mice) that forms the endocardial cushions in the atrioventricular (AV) and conal outflow tract (OFT) regions of the developing heart[29,30]. Endocardial cushions are the primordia of valves and septa, and become mature structures through remodeling (E10.5-E18.5) and valve elongation and maturation (E14.5 to 1 week after birth). Heart valve remodeling can be conceptually organized into multiple aspects, including mesenchymal expansion (E10.5-E12.5), differentiation (E12.5-E16.5), and condensation (E15.5-E18.5), all of which occur in a temporally overlapping fashion[31]. It is very difficult to establish precisely when valvulogenesis formally ends. However, by systematic analysis of valve condensation, elongation, formation of nodular thickenings, and remodeling of tension-resistant ECM proteins in mouse valves from E15.5 to the 8-weeks-old stage, it has been demonstrated that valvulogenesis continues after birth to adjust to the postnatal maturation of the heart[32]. During the maturation process, the ECM of AV or OFT valves is organized into and maintained during adulthood as three distinct layers relative to blood flow: atrialis or ventricularis, spongiosa, and fibrosa[10].

\section{INVOLVMENT OF PERIOSTIN AND TGF $\beta$ SUPERFAMILY MEMBERS IN HEART VALVE DISEASES}

Current evidence supports the involvement of periostin, TGF $\beta$ s, and BMPs in both inherited congenital (bicuspid aortic valve and polyvalvular disease) and acquired valvular diseases affecting more than one valve type[21,25,33,34]. In mammals, the TGF $\beta$ subfamily has three members (TGF $\beta 1$, TGF $\beta 2$, and TGF $\beta 3$ ) and over 20 BMP members constitute the BMP subfamily[35,36]. Periostin is a 90-kDa secreted 


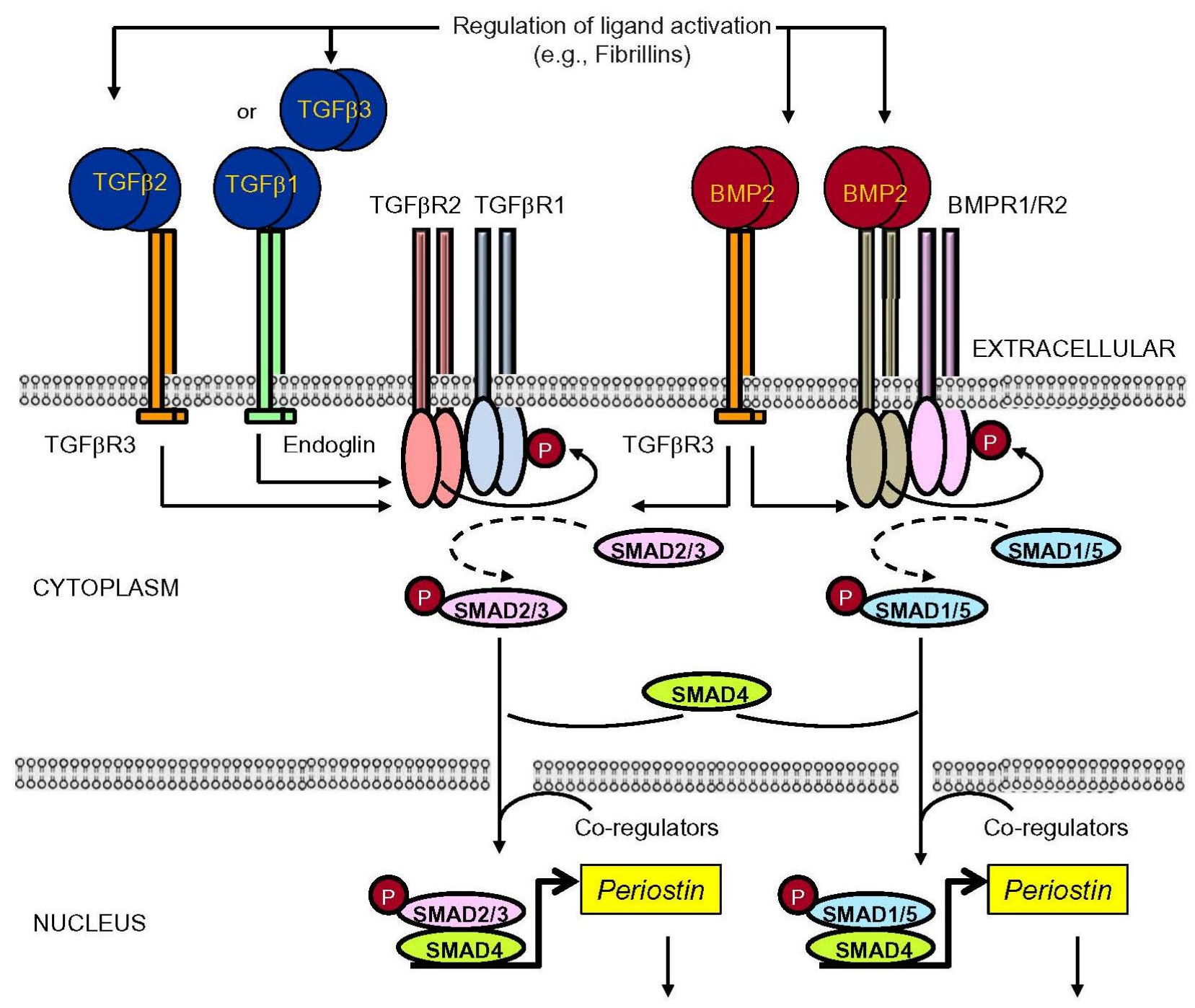

Valve development and remodeling, and valve homeostasis

FIGURE 1. Schematic diagram illustrating the signaling events involving TGF $\beta$, BMP, and perisotin. This association is based mostly on in vitro data and that this inter-relationship has not been completely proven in vivo. The major highlight of this illustration is that both TGF $\beta 2$ and BMP2 bind to TGF $\beta$ R3, and signal through the canonical TGF $\beta$ signaling pathway during valve formation, which could affect periostin. ECM molecules, such as fibrillin-1, can restrict bioavailability of both TGF $\beta$ and BMP ligands. In the canonical TGF $\beta$ pathway, endoglin associates with TGF $\beta 1$ and TGF $\beta 3$ with a higher affinity than that of TGF $\beta 2$. TGF $\beta$ R3 is a high-affinity receptor of TGF $\beta 2$. Both endoglin and TGF $\beta$ R3 facilitates ligand binding to the canonical TGF $\beta$-receptor (TGF $\beta$ R 1/TGF $\beta$ R2) heteromeric complex. This results in phosphorylation of the TGF $\beta$-specific SMADs (i.e., pSMAD2/3). The pSMAD2/3 forms a complex with SMAD4, which accumulates in the nucleus and can regulate Postn. Canonical BMP2 signaling occurs through BMP receptors and BMP-specific SMADs (i.e., SMAD1/5/8). BMP signaling has also been shown to induce Postn. Based on the individual activities of TGF $\beta$, BMPs, and periostin in valvulogenesis, it is likely that this inter-relationship may play an important role in valvular heart diseases. See the text for more discussion. 
protein that is involved in both valve development and valvular heart disease[21,37,38]. Periostin gene (Postn) knockout (hereafter termed Postn ${ }^{-1}$ ) mice have abnormal semilunar and AV valves, and periostin deficiency is associated to the stenotic bicuspid aortic valve in pediatric patients[21,39]. It is paradoxically elevated in diseased or thickened mitral valves in Scleraxis null mice[40]. TGF $\beta 2$ gene (Tgfb2) knockout (hereafter termed $T g f b 2^{-/}$) mice have multiple structural defects, including thickened valves[41,42,43]. Genetic mutations in FIBRILLIN-1 (and in the Fibrillin-1 ${ }^{+/ \mathrm{C} 1039 \mathrm{G}}$ mouse model for Marfan syndrome), TGFBR1/2, FILAMIN A (encodes SMAD2-interacting protein), SMAD3, and SMAD4 (common SMAD molecule for both TGF $\beta$ and BMP signaling), which are mediators of TGF $\beta$ and/or BMP signaling, are also associated with congenital valve diseases affecting inlet and/or outlet valves[17,19,33,34,44,45]. Many of these genetic mutations result in paradoxically increased TGF $\beta$ signaling[44,46,47]. Increased TGF $\beta 1$ and/or BMP2 signaling have also been reported in patients of valvular heart diseases, including chronic rheumatic heart disease and calcified human aortic valves[7,48,49]. Cardiac valve thickening is also associated with increased $T g f b l$ expression in response to serotonin agonists and to anti-Parkinson's disease drugs (dopamine agonists), such as pergolide and cabergoline[14,48]. The diagnosis of valvular heart diseases is typically done by echocardiography. There is no effective treatment to date to prevent the progressive changes in these valves and the patients often require surgery. The causes of various forms of valve diseases (i.e., stenotic/carcinoid/rheumatic/calcific) remain largely unclear. In this review, we have accumulated current evidence that suggests an association of periostin to TGF $\beta$ and BMP signaling in the pathogenesis of valve disease, which affects one or more valve types.

\section{ROLE OF PERIOSTIN IN VALVULOGENESIS}

Periostin is a fasciclin domain-containing protein that plays important roles in the development and function of the cardiovascular system[37,38,50]. TGF $\beta$-inducible protein (TGF $\beta$ i/ $\beta$ igH3) and Stabilin-1 and Stabilin-2 are other similar proteins, and their role in cardiac development is discussed elsewhere[51]. As a secreted ECM protein that associates with areas of fibrosis, periostin can directly interact with other ECM proteins, such as fibronectin, tenascin-C, collagen I, collagen V, and heparin sulfate proteoglycans. Periostin serves as a ligand for select integrins, such as $\alpha v \beta 3, \alpha v \beta 5$, and $\alpha 4 \beta 6$, where it can affect the ability of cells (fibroblasts or cancer cells) to migrate and/or undergo mesenchymal transformation in select tissues[52,53,54]. Therefore, it is hypothesized that periostin can also signal through the integrin pathway during normal development and homeostasis. The mouse periostin gene (Postn) shows a dynamic expression profile, both developmentally and in adult tissues that are undergoing remodeling or active stress (reviewed[51]). Periostin is expressed in fibroblasts or in cells that adopt fibroblast-like characteristics following an injury event[21]. It has also been demonstrated that periostin is highly produced by cancer-associated fibroblasts or tumor stromal cells in various types of cancers, and in mature and developing heart valves[54,55]. Interestingly, periostin as well as TGF $\beta$ and BMP ligands are reported to be associated with cancer progression[56,57,58,59,60]. Periostin was first identified in osteoblast-like cells[61], and it is thought to play important roles in bone formation and development of periodontal ligaments[62,63]. Notably, periostin and TGF $\beta$ and BMP ligands are all involved in osteochondrogenesis[33,36,64]. Osteochondrogenesis has emerged as an important process in heart development and remodeling, and in the pathogenesis of valve disease[65,66]. The lesson learned from the many similarities between the roles of periostin and TGF $\beta$ and BMP signaling in cancer and bone/cartilage formation is that there may be an association between periostin and TGF $\beta$ and BMP signaling in the osteochondrogenic process that occurs during valvulogenesis.

In valvulogenesis, periostin is expressed in the differentiating cardiac cushion mesenchyme, but is absent from the cardiomyocyte lineage[21,55]. Although expression of the gene for TGF $\beta \mathrm{i} / \beta \mathrm{igH} 3 \mathrm{has}$ some similarity with that of Postn, it is additionally expressed in the cushion myocardium in the outflow tract and is not expressed in AV cushions. On the other hand, Stabilin-1 gene expression is limited to the 
endocardium and has no overlap with Postn[51]. To investigate the role of periostin in heart valve development, we and others have generated mice that lack Postn[21,51]. The majority of Postn ${ }^{-/}$mice survive, but they have abnormally shortened and thickened valve leaflets. A smaller percentage of these mice die before the weaning stage and valves in these mice are shorter than in the surviving Postn ${ }^{-/}$mice. Both semilunar and AV valves are affected[21,39]. Adult Postn ${ }^{-/}$mice show disrupted collagen matrix layers and higher than normal accumulation of valve matrix proteoglycans. In addition, the presence of ectopic cardiomyocytes and smooth muscles in valve leaflets is also noted in these mice. Some of these changes are consistent with the presence of a general valve pathology in these mice that can be associated with the onset and progression of mitral valve prolapse, aortic or pulmonary valve stenosis, and aortic regurgitation and calcification[21,22,28,67]. Overall, this suggests that loss of periostin results in inappropriate differentiation of mesenchymal cushions and in valvular abnormalities during establishment of valve leaflets.

\section{TGF $\beta$ AND BMP SIGNALING}

There are 33 members in the mammalian TGF $\beta$ family, which include TGF $\beta$ s, BMPs, activins and inhibins, nodal, myostatin, and the anti-Müllerian hormone[36]. TGF $\beta$ and BMP ligands are produced as large inactive complexes that are sequestered by a variety of ECM molecules, including fibronectin and fibrillins[36,68]. Current evidence suggests that the lack of fibrillin-1 could lead to ectopic activation of latent TGF $\beta$ and/or BMP ligands, which can then cause hyperactivated intracellular TGF $\beta$ and/or BMP signaling[69]. TGF $\beta$ s usually interact with TGF $\beta$ R2 and TGF $\beta$ R1 (also called as ALK5) receptors[70], sometimes in conjunction with the type III TGF $\beta$ receptor (TGF $\beta$ R3)[71] or endoglin[72], resulting in phosphorylation-dependent activation and nuclear localization of SMAD2/3 in association with SMAD4 (Fig. 1). TGF $\beta 1$ is also capable of signaling through ALK1 (a BMP type I receptor) in conjunction with endoglin in endothelial cells, thereby bringing about a cross-talk between ALK1- and ALK5-mediated TGF $\beta$ signaling[73,74]. Additionally, extracellular cues (e.g., fibronectin, periostin, and cell-cell contacts) acting through integrins can also affect TGF $\beta$ signaling[75]. TGF $\beta$ s can also signal through several other pathways, such as the RAS-MAPK and retinoid pathways[70,76,77]. As with the TGFßs, the BMP subfamily of ligands also signals through a variety of type I and II receptors from which transduction occurs via SMADs 1, 5, and 8 in combination with SMAD4[36,78] (Fig. 1). The inhibitory SMAD6 predominantly inhibits BMP signaling, whereas SMAD7 inhibits both TGF $\beta$ and BMP signaling[79,80]. Recently, it has been shown that BMP2 can signal through TGF $\beta$ R3, a canonical TGF $\beta$ receptor, in cardiac cushion EMT[81,82] (Fig. 1). Furthermore, ALK2, a BMP type I receptor, can participate in the TGF $\beta$-dependent canonical SMAD2/3-mediated pathway[83]. Collectively, it appears that TGF $\beta$ and BMP ligands have both independent as well as overlapping activities during tissue development and homeostasis. In this review, we summarize some of these activities in the context of heart valve development and valvular heart disease (see below).

\section{ROLE OF TGF $\beta$ SIGNALING IN VALVULOGENESIS}

Some clarity for TGF $\beta$ ligand specificity in heart valve development has been afforded by expression studies[23,84,85,86,87,88,89]. Briefly, Tgfb2 is highly expressed during EMT (E9.5) within the cushion myocardium and its expression increases in the cushion mesenchyme during cushion remodeling (E12.5E15.5). Intriguingly, TGF $\beta 2$ protein staining of the myocardium persists throughout development and in the adult, in the absence of detectable levels of the corresponding Tgfb2 transcript[87]. Tgfb1 is expressed predominantly in the endocardium (E9.5-onward) throughout development and neonates[84,86]. Tgfb3 expression is limited to a subset of $T g f b 2$-expressing cushion mesenchymal cells and occurs only at later stages of cushion remodeling (E12.5-E16.5) during valvulogenesis[84,88]. Careful analysis of published 
expression data of Tgfb1-3 and Postn has also indicated that there is an overlap in the Postn expression with that of $T g f b 2$ and $T g f b 3$ during valvulogenesis[21,55,84]. Analysis of $T g f b 1-3$ expression in adult mouse heart valves has not been done. Interestingly, there is significant Postn expression in postnatal valves, which is consistent with its important role in adult valve homeostasis[21].

Recently, serial analysis of gene expression (SAGE) profiling has been done to determine the genome-wide transcriptional patterns of the developing heart valves during EMT and cushion remodeling (E9.5-E12.5)[89]. SAGE permits the simultaneous evaluation of thousands of expressed transcripts, generating absolute values that are easily compared. For instance, SAGE data show that expression of $T g f b 2$ is found to be high at E9.5-10.5 and then decreases over time, while $T g f b 3$ expression is increased as valve development proceeds. While the in vivo roles of TGF $\beta 1$ and TGF $\beta 3$ in heart development remain unclear, this increased $T g f b 2$ expression during the early heart development is consistent with the important role of TGF $\beta 2$ in the initiation and cessation of cushion EMT and cushion remodeling[42]. The fact that $T g f b 3$ expression is on the rise as valve development proceeds into advanced stages of heart development suggests that TGF $\beta 3$ may play an important role in valve structure and function in postnatal mouse hearts. This speculation is consistent with the observations that genetic mutations or genetic polymorphisms in human TGFB3 are involved in adult heart diseases[90,91]. Similarly, several studies have indicated an important role of periostin in adult heart diseases [51,92].

Although the functions of the TGF $\beta$ family members and receptors in EMT are well studied, their role in valve remodeling and maturation remains to be fully explored. There is some confusion about the role of TGF $\beta$ ligands in EMT during heart development or adult cardiac valves in mammals[30,93]. In vitro studies have suggested that while only TGF $\beta 2$ is required for EMT in mice and humans, addition of the other TGF $\beta$ ligands can also induce EMT in chickens and sheep in embryonic and adult hearts[23,85,93]. There is no report of significant cardiac developmental defects in TGF $\beta 1$ - or TGF $\beta 3$ deficient mice[42,94,95]. On the other hand, consistent with the dominant expression in developing hearts, only $T g f b 2^{-/}$mice exhibit abnormal EMT, enlarged valves, and other congenital cardiovascular malformations[42,96]. Since gene expression data suggest that TGF $\beta 2$ and TGF $\beta 3$ could play roles in valve maturation within the valvular mesenchyme where Postn is also expressed, and since TGF $\beta 1$ could be playing a juxtacrine/paracrine role from the valvular endocardium, further investigation is warranted to determine the functions of the TGF $\beta$ s and their association with periostin in valvulogenesis.

\section{ROLE OF BMP SIGNALING IN VALVULOGENESIS}

BMP2, 4, 5, 6, and 7 are the most studied members of the BMP subfamily of ligands in the cardiovascular system[97]. Bmp2 is expressed in the AV myocardium during EMT, then switches to the cellularized cushion mesenchyme, where its expression continues throughout valvulogenesis[98,99]. Bmp4 is expressed in both the AV and OFT myocardium[100]. Bmp6 and Bmp7 are coexpressed in the OFT myocardium, and Bmp6 is uniquely expressed in the AV cushion mesenchyme, but not the OFT mesenchyme (reviewed[101]). With regard to the involvement of BMP signaling in heart valve disease, activated BMP signaling (as measured by pSMAD1/5/8) has been observed in diseased human aortic valves[7]. Bmp2 is significantly expressed in adult mouse valves[102]. In humans, while the levels of BMP2 are significantly detectable in diseased valves, they are not detectable in normal human valves[49]. Moreover, BMP4 levels are highly abundant in adult cardiac valves[103]. This expression of BMP ligands in adult heart valves is consistent with the report signifying an in vivo genetic interaction between $B m p 2$ and $B m p 4$ as indicated by valve abnormalities in $B m p 2^{+/-} B m p 4^{+/-}$adult mice[104]. Since periostin is also abundantly expressed in mature or adult valves[21], these findings suggest a coinciding expression of BMP4 and periostin in adult cardiac valves. These expression data also suggest that, to a large degree, BMP2 plays an important role in AV valve development; whereas BMP4, 6, and 7 are important for OFT valve development; and that BMP4 may be important for valve maturation and maintenance in adults. 
Overall, as with some TGF $\beta$ ligands, there appears to be significant overlap in expression of specific BMP ligands and periostin during valvulogenesis and in adults.

At the functional level, the role of BMP ligands and BMP signaling in valvulogenesis is somewhat better understood than that of TGF $\beta$ ligands and TGF $\beta$ signaling. Here, we have summarized some significant studies highlighting the effect of loss-of-function and gain-in-function of BMP signaling on valve phenotype during heart development. A Bmpr2 hypomorph has OFT defects, persistent truncas arteriosis, and hypoplastic semilunar valves, but no AV valve defects[105]. Bmp $6^{-1-} B m p 7^{-1-}$ double knockout mice also have hypoplastic OFT cushions and semilunar valves[101]. Heart-specific (Nkx2.5Cre) conditional deletion of a floxed Bmp2 allele leads to multiple defects in AV canal morphogenesis ranging from EMT to specification of the AV myocardium[98]. A similar approach to conditional mutation of Bmp4 leads to OFT septation defects and hypoplastic OFT valves[100,106]. Intriguingly, conditional deletion of Bmp4 in second heart-field lineage or endothelial-specific deletion of Bmpr2 leads to hyperplastic or thickened valves[107,108]. It is noteworthy that gain of BMP function in Noggin $^{-1-}$ (a dedicated BMP antagonist) and Smad6 ${ }^{-1-}$ (Bmp-specific nuclear inhibitor) mice similarly results in thickened or hyperplastic valves[109,110]. Thus, these findings suggest that a genetic defect or loss-of-function in the BMP pathway activates major compensatory changes that culminate in a paradoxically excessive BMP and/or TGF $\beta$ response and valve thickening. These findings are in parallel to the studies indicating that both increased and decreased periostin and TGF $\beta$ signaling can cause valve thickening[17,21,40]. Overall, as with periostin and TGF $\beta$ s, dysregulated BMP signaling can cause valve thickening.

\section{EVIDENCE OF THE INTER-RELATIONSHIP BETWEEN PERIOSTIN, TGF $\beta$, AND BMP SIGNALING}

Several recent studies have pointed to a cross-talk between TGF $\beta$ and BMP signaling that bears significant relevance to the inter-relationships between periostin, TGF $\beta$, and BMP in valvulogenesis:

1. Bmp2 is expressed in a similar fashion to $T g f b 2$ in AV cushions during cushion formation in the mouse, and absence of $B M P 2$, which results in down-regulation of $T g f b 2$, leads to complete shutdown of cushion EMT in mouse AV explant cultures[98,111]. This is consistent with the delayed augmentation of EMT in vivo in cushion formation in $T g f b 2^{-/}$mice[42].

2. TGF $\beta$ R3, a high-affinity receptor of TGF $\beta$, can bind with equal affinity to BMP2 and can lead to cushion EMT[81].

3. EMT as well as the phosphorylation of SMAD1/5/8 signaling can occur in the absence of endocardial-Bmpr2, indicating that BMP2 can signal through TGF $\beta$ or activin type II receptors[107].

4. TGF $\beta$ ligands can induce both TGF $\beta$ - and BMP-specific SMADs[83,112].

5. Endothelial-specific deletion of $A l k 2$, a BMP type 1 receptor, leads to the down-regulation of both TGF $\beta$ - and BMP-specific SMADs[113].

6. Postn and Tgfb and Bmp ligand genes express in remodeling cushions, and periostin and $T g f b 2$ are decreased in the absence of ALK3[114].

As BMP2 has also been shown to induce $T g f b 2$ [98], and as BMP2 is known to function synergistically with $T g f b 3$ in the regulation of endocardial cushion morphogenesis[115], it is possible that the effect of BMP signaling on Postn[21] is mediated by activating an endocardial TGF $\beta$ autocrine loop. Thus, it is currently not clear whether TGF $\beta 2$ and BMP2 share some common receptor(s) and SMAD(s) in cushion formation in vivo, and whether this cross-talk has relevance to periostin function in valvulogenesis. 


\section{MOLECULAR REGULATION OF PERIOSTIN BY TGF $\beta$ AND BMP SIGNALING, AND ITS IMPLICATIONS IN VALVULOGENESIS}

Despite the complex and intriguing correlation of deregulated Postn expression levels in both normal and pathological transformation conditions, very little is known about how Postn is transcriptionally controlled. Recently, a $3.9-\mathrm{kb}^{\text {Postn }}$ proximal promoter was isolated to understand the molecular regulation

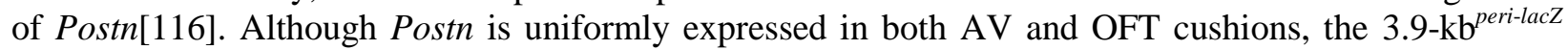
reporter expression is restricted to a subpopulation of distal OFT endocardial cushion cells. This indicates that elements required for AV cushion expression are absent from the $3.9-\mathrm{kb}^{\text {Postn }}$ promoter and may lie outside this $3.9-\mathrm{kb}^{\text {Postn }}$ domain. It is not clear whether the $3.9-\mathrm{kb}^{\text {Postn }}$ cell lineage can populate or colonize AV cushions later during valvulogenesis. In order to identify the enhancer and associated DNA binding factor(s) responsible for the restricted Postn expression, we identified a minimal 37-bp region within the 3.9-kb $\mathrm{kb}^{\text {Post }}$ enhancer that is a binding site to the ubiquitous Ying Yang-1 (YY1) transcription factor. This YY1-binding was shown to be essential for in vivo 3.9-kb ${ }^{\text {peri-lacz }}$ promoter activity. Published data show that SMAD-mediated modulation of YY1 activity can regulate BMP responses and cardiac-specific expression of a GATA4/5/6-dependent $N k x 2.5$ enhancer[117]. Thus, YY1 could be acting as a novel SMAD-interacting protein that represses SMAD transcriptional activities in a gene-specific manner and therefore regulates cell differentiation induced by TGF $\beta$ superfamily pathways[118]. Thus, whether TGF $\beta$ and/or BMP signaling regulates transcription of Postn via a direct regulation of the $3.9-\mathrm{kb}^{\text {Post }}$ enhancer sequences should be explored.

Interesting correlations are observed between the mesenchymal gene expression patterns of $T g f b 2$ and Tgfb3 and Postn, and between membrane-restricted Tgfbl and Stabilin1, suggesting a functional interaction between fasciclin domain-containing proteins and specific TGF $\beta$ ligands[51,84]. In vitro studies have shown that Postn expression is positively regulated by TGF $\beta 1[119,120]$. Periostin levels are reduced in cardiac fibroblasts of $T g f b 2^{-/-}$mouse embryonic hearts[50]. In chick AV cushions, TGF $\beta 3$ has been reported to induce periostin[121]. In addition, periostin is required for TGF $\beta$ signaling (i.e., pSMAD2) in vivo and TGF $\beta$ responsiveness in vitro in mouse embryonic fibroblasts (MEFs)[21]. Also, we reported that Postn is up-regulated in rat carotid arteries following balloon injury and in cultured vascular smooth muscle cells after stimulation with TGF $\beta 1$, and that up-regulation is mediated via PI3kinase[122].

There is circumstantial evidence that while TGF $\beta 1$ can induce Postn in vitro and under pathophysiological conditions[120], it is possible that TGF $\beta 2$ is the more likely inducer of Postn in vivo during valvulogenesis. Histological examination of hematoxylin and eosin (H\&E)-stained serial sections showed that $T g f b 2^{-/}$mice, and not $T g f b 1^{-/}$and $T g f b 3^{-/-}$mice, develop valve thickening as seen in Postn ${ }^{-/}$ mice[21,42]. It is currently not clear as to how TGF 32 and periostin are connected. Since both the Postnexpressing 3.9-kb ${ }^{\text {peri-lacz }}$ cell lineage and cardiac neural crest cells (NCC) are predominantly restricted to the cardiac OFT[116,123,124], defects in one or both of these populations could result in abnormal OFT cushions in $T g f b 2$ knockout mice. Through lineage tracking in Wnt1Cre R26R $T g f b 2^{-/}$embryos, no significant defect in the migration of cardiac NCC has been observed[125]. However, this does not rule out the possibility of an abnormal postmigratory NCC function in cardiac OFT cushions. On the other hand, valve maturation defects in both Posth $^{-/-}$and $T g f b 2^{-/-}$mice raise the possibility that there is a defect in Postn-expressing OFT cells in $T g f b 2^{-/-}$mice. Another possibility is that there is an excessive amount of active TGF $\beta 1$ in $T g f b 2^{-/}$valves, which may increase periostin production and cause valve thickening, an association seen in vitro in cell culture (i.e., dermal fibroblast), and in vivo in mice and humans with heart diseases (see below)[17,21,92,120,126]. Collectively, these published findings lead to speculation that excessive amounts of active TGF $\beta 1$, hereinafter called "pathological TGF $\beta 1$ " levels, may induce periostin and result in enlarged valves.

Disrupted ECM organization in Posth ${ }^{-1-}$ mice is another mechanism by which excessive TGF $\beta 1$ activation and valve thickening can occur. Disrupted ECM leads to enhanced levels of active TGF $\beta 1$ (e.g., pSMAD2) and valve thickening in Fibrillin1-deficient mice[17,46]. It has also been shown that 
higher levels of TGF $\beta 1$ can lead to myofibroblast differentiation of valvular cells in vitro[127]. Posth ${ }^{-/}$ mice have aberrant valve muscularization, suggesting that loss of periostin results in inappropriate differentiation of valvular fibroblasts into myocardial or activated fibroblasts (i.e., myofibroblasts[21]). In avian models with experimentally induced cardiac abnormalities, it has been found that periostin is decreased, which correlates with valve thickening and persistent AV myocardial connections (e.g., WolffParkinson White syndrome)[128]. The status of TGF $\beta$ signaling and its correlation to periostin and valve thickening are not determined in this avian model study. Consequently, we speculate that mouse models that produce pathological TGF $\beta 1$ during valvulogenesis will be useful in order to understand whether pathological TGF $\beta 1$ is sufficient for Postn and valve thickening in the absence of fibrosis. This will also illuminate the contribution of $T g f b 1$ overexpression in several valvular diseases[46,48].

Postn expression is also induced in vitro by BMP signaling in cell culture experiments[129]. Postn is initially expressed at normal levels in E11.5 cushions of AV canal myocardium-specific conditional mutants of the BMP type 1 receptor (ALK3), but it is appreciably reduced in these mutant E14.5 AV leaflets[114]. Given that $T g f b 2$ expression is also decreased in Alk $3^{--}$mutants, the cardiac cushions of mutant mice may therefore be hypoplastic secondarily to decreased TGF $\beta 2$-mediated endocardial cushion EMT. This notion is also supported by our published findings indicating that TGF $\beta 2$ promotes early-stage EMT in the mouse[42]. In addition, gene-targeted deletion of Postn as well as Smad6 or Noggin has revealed that both periostin and BMP signaling are required for normal valve formation and prevention of inappropriate differentiation along chondrogenic and bone lineages[21,109,110]. Our data have revealed that Postn is up-regulated in hyperplastic cushions of Smad $6^{-1-}$ hearts[21]. Thus, altered BMP signaling is upstream and may modulate Postn regulation, so that when the inhibitory SMAD or BMP antagonist are removed (leading to elevated BMP signaling), periostin is up-regulated. In support of this, exogenous chick Bmp2 or constitutively active Alk6 (type IB BMP receptor) retrovirus significantly promoted expression of Postn in AV cushion explant assays[130].

\section{PERSPECTIVES}

The molecular regulation of Postn by TGF $\beta$ and BMP signaling as presented here is based on the association of these molecules and has not been proven (Fig. 2). Investigation into the regulation of Postn by TGF $\beta$ and BMP signaling during early development of OFT cushions and in the colonization of AV cushions would provide important information about the underlying mechanisms involved in valvulogenesis. Lineage analysis already demonstrates that the $3.9-\mathrm{kb}^{\text {Postn }}$ promoter marks a subpopulation of OFT cushion cells. It is unclear whether these $3.9-\mathrm{kb}^{\text {Postn }}$ marked cells can contribute to the AV valves during the later stages of valve development. It is unclear whether additional cis-elements that may lie outside the $3.9-\mathrm{kb}^{\text {Postn }}$ domain are necessary for the AV cushion recruitment of the $3.9-\mathrm{kb}^{\text {Postn }}$ marked cells. It remains to be determined if the AV cushion recruitment of the $3.9-\mathrm{kb}^{\text {Postn }}$-marked OFT cushion cells is TGF $\beta$ and/or BMP dependent. The $3.9-\mathrm{kb}^{\text {Postn }}$ enhancers can be utilized to drive novel tissue-specific expression of Cre recombinase in transgenic mice and to distinguish inlet vs. outflow cushion morphogenesis. Given the current lack of any robust cardiac mesenchyme-restricted promoters that work both in embryonic heart development and adult heart valves (in valve interstitial cells and cardiac fibroblasts), 3.9-kb ${ }^{\text {Post }}$-Cre driver mouse lines may provide useful tool mice for the scientific community interested in cardiac development and disease.

It is noteworthy that periostin is found in osteoblast-like cells and that it is dysregulated in various forms of cancer. The processes of valvulogenesis, osteogenic and chondrogenic development, and tumorigenesis have many features in common. For instance, periostin and TGF $\beta$ s and BMPs are all reported to be associated with cancer progression and osteochondrogenic processes (e.g., calcification of bones and valves). Since both TGF $\beta$ s and BMPs play important roles in similar processes and their roles in these processes are currently better understood than that of periostin, the information gained from these other fields of study should provide additional clues about periostin function and its regulation during 


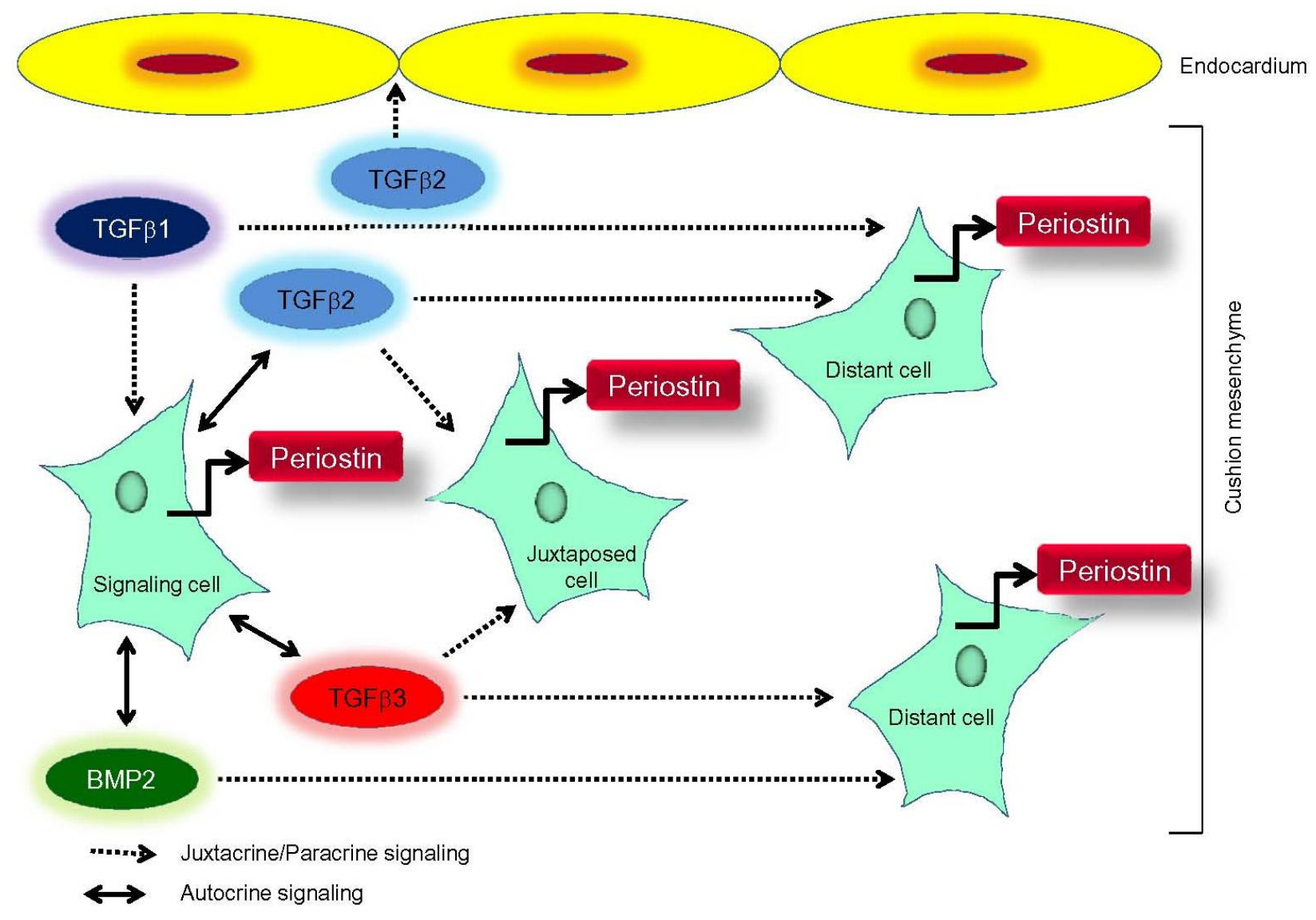

FIGURE 2. The inter-relationship of periostin, TGF $\beta$ s, and BMP2 in AV cushion remodeling during heart development. In this model, periostin is tied up to a network of TGF $\beta$ and BMP signaling, which is required for various aspects of valvulogenesis, such as matrix organization, suppression of nonvalvular phenotypes (i.e., ectopic presence of bone and cartilage lineage) and valve differentiation, and valve structure and function in adult hearts (see the text for details). Depiction of the cell type-specific patterns of expression of TGF $\beta$ and BMP ligand genes and periostin during cushion remodeling is based on published data. Speculation about the role of cell autonomous and nonautonomous action of the TGF $\beta$ and BMP signaling network on perisotin is also based on published information. Briefly, TGF $\beta 2$, TGF $\beta 3$, and BMP2 are predominantly produced in the cushion mesenchyme, where they could engage in autocrine (double-headed arrows) and juxtacrine and paracrine (dotted arrows) signaling to induce Postn during cushion remodeling. Autocrine signaling shows that TGF $\beta$ or BMP ligands are secreted or produced by and act on the same cell. The term juxtacrine signaling is used here to highlight the action of the secreted TGF $\beta$ or BMP ligands on the adjacent cell. Paracrine signaling refers to the action of the secreted TGF $\beta$ or BMP ligands on a distant cell population in the remodeling cushions. Cushion mesenchymal TGF $\beta 2$ has been shown to have an important paracrine/juxtacrine role in the cessation of cushion EMT. TGF $\beta 1$ is primarily seen in the cushion endocardium during heart development. Since it can induce Postn in different cell types in vitro, it is possible that TGF $\beta 1$ could have a paracrine/juxtacrine effect on periostin in the cushion mesenchyme. Consequently, it appears that the cushion mesenchyme have various contingent sources and mechanisms to produce and sustain periostin during valvulogenesis. The model presented here on the molecular regulation of periostin by TGF $31-3$ and BMP2 in the context of valvulogenesis is predominantly based on the published association of these molecules and is not proven (see the text for further details). 
valvulogenesis. Several studies that are summarized here have called for an investigation to delineate the relationship between periostin and TGF $\beta$ and BMP signaling, and how these molecules influence valve thickening (Fig. 2). In summary, clarifying the inter-relationship between periostin, TGF $\beta$, and BMP during heart development and in adult valve homeostasis will lead to a better understanding about the pathogenesis of valvular heart diseases.

\section{ACKNOWLEDGMENTS}

This work was supported, in part, by the Indiana University Department of Pediatrics (Cardiology), Riley Children's Foundation, BIO5 Institute (University of Arizona), Arizona Biomedical Research Commission Project \#0901, and the National Institutes of Health (NIH) grants R01 HL60714, P01 HL85098, R01 HL092508, HL070174, HL105280.

\section{REFERENCES}

1. Pierpont, M.E., Basson, C.T., Benson, D.W., Jr., Gelb, B.D., Giglia, T.M., Goldmuntz, E., McGee, G., Sable, C.A., Srivastava, D., and Webb, C.L. (2007) Genetic basis for congenital heart defects: current knowledge: a scientific statement from the American Heart Association Congenital Cardiac Defects Committee, Council on Cardiovascular Disease in the Young: endorsed by the American Academy of Pediatrics. Circulation 115, 3015-3038.

2. Supino, P.G., Borer, J.S., Yin, A., Dillingham, E., and McClymont, W. (2004) The epidemiology of valvular heart diseases: the problem is growing. Adv. Cardiol. 41, 9-15.

3. Cripe, L., Andelfinger, G., Martin, L.J., Shooner, K., and Benson, D.W. (2004) Bicuspid aortic valve is heritable. J. Am. Coll. Cardiol. 44, 138-143.

4. Siu, S.C. and Silversides, C.K. (2010) Bicuspid aortic valve disease. J. Am. Coll. Cardiol. 55, 2789-2800.

5. Bartram, U., Bartelings, M.M., Kramer, H.H. and Gittenberger-de Groot, A.C. (2001) Congenital polyvalvular disease: a review. Pediatr. Cardiol. 22, 93-101.

6. Ward, C. (2000) Clinical significance of the bicuspid aortic valve. Heart 83, 81-85.

7. Wirrig, E.E., Hinton, R.B. and Yutzey, K.E. (2011) Differential expression of cartilage and bone-related proteins in pediatric and adult diseased aortic valves. J. Mol. Cell. Cardiol. 50, 561-569.

8. $\quad$ Caira, F.C., Stock, S.R., Gleason, T.G., McGee, E.C., Huang, J., Bonow, R.O., Spelsberg, T.C., McCarthy, P.M., Rahimtoola, S.H., and Rajamannan, N.M. (2006) Human degenerative valve disease is associated with up-regulation of low-density lipoprotein receptor-related protein 5 receptor-mediated bone formation. J. Am. Coll. Cardiol. 47, 1707-1712.

9. $\quad$ Barber, J.E., Kasper, F.K., Ratliff, N.B., Cosgrove, D.M., Griffin, B.P., and Vesely, I. (2001) Mechanical properties of myxomatous mitral valves. J. Thorac. Cardiovasc. Surg. 122, 955-962.

10. Wirrig, E.E. and Yutzey, K.E. (2011) Transcriptional regulation of heart valve development and disease. Cardiovasc. Pathol. 20, 162-167.

11. Lucas, R.V., Jr. and Edwards, J.E. (1982) The floppy mitral valve. Curr. Probl. Cardiol. 7, 1-48.

12. Tamura, K., Fukuda, Y., Ishizaki, M., Masuda, Y., Yamanaka, N., and Ferrans, V.J. (1995) Abnormalities in elastic fibers and other connective-tissue components of floppy mitral valve. Am. Heart J. 129, 1149-1158.

13. Grande-Allen, K.J., Griffin, B.P., Ratliff, N.B., Cosgrove, D.M., and Vesely, I. (2003) Glycosaminoglycan profiles of myxomatous mitral leaflets and chordae parallel the severity of mechanical alterations. J. Am. Coll. Cardiol. 42, 271277.

14. Roth, B.L. (2007) Drugs and valvular heart disease. N. Engl. J. Med. 356, 6-9.

15. Gelb, B.D. (2006) Marfan's syndrome and related disorders--more tightly connected than we thought. N. Engl. J. Med. 355, 841-844.

16. Hennekam, R.C. (2005) Severe infantile Marfan syndrome versus neonatal Marfan syndrome. Am. J. Med. Genet. A 139, 1.

17. Ng, C.M., Cheng, A., Myers, L.A., Martinez-Murillo, F., Jie, C., Bedja, D., Gabrielson, K.L., Hausladen, J.M., Mecham, R.P., Judge, D.P., and Dietz, H.C. (2004) TGF-beta-dependent pathogenesis of mitral valve prolapse in a mouse model of Marfan syndrome. J. Clin. Invest. 114, 1586-1592.

18. Flores, M., Agosti, J., Damborenea, C., and Aguirre, C. (1984) Rheumatoid arthritis with severe aortic insufficiency and prolapse of the mitral valve. Scand. J. Rheumatol. 13, 28-32.

19. Kyndt, F., Gueffet, J.P., Probst, V., Jaafar, P., Legendre, A., Le Bouffant, F., Toquet, C., Roy, E., McGregor, L., Lynch, S.A., Newbury-Ecob, R., Tran, V., Young, I., Trochu, J.N., Le Marec, H., and Schott, J.J. (2007) Mutations in the gene encoding filamin A as a cause for familial cardiac valvular dystrophy. Circulation 115, 40-49. 
20. Weismann, C.G. and Gelb, B.D. (2007) The genetics of congenital heart disease: a review of recent developments. Curr. Opin. Cardiol. 22, 200-206.

21. Snider, P., Hinton, R.B., Moreno-Rodriguez, R.A., Wang, J., Rogers, R., Lindsley, A., Li, F., Ingram, D.A., Menick, D., Field, L., Firulli, A.B., Molkentin, J.D., Markwald, R., and Conway, S.J. (2008) Periostin is required for maturation and extracellular matrix stabilization of noncardiomyocyte lineages of the heart. Circ. Res. 102, 752-760.

22. Markwald, R.R., Norris, R.A., Moreno-Rodriguez, R., and Levine, R.A. (2010) Developmental basis of adult cardiovascular diseases: valvular heart diseases. Ann. N. Y. Acad. Sci. 1188, 177-183.

23. Azhar, M., Schultz, J.E., Grupp, I., Dorn, G.W., Meneton, P., Molin, D.G., Gittenberger-de Groot, A.C., and Doetschman, T. (2003) Transforming growth factor beta in cardiovascular development and function. Cytokine Growth Factor Rev. 14, 391-407.

24. Arthur, H.M. and Bamforth, S.D. (2011) TGFbeta signaling and congenital heart disease: insights from mouse studies. Birth Defects Res. A Clin. Mol. Teratol. 91, 423-434.

25. Hakuno, D., Kimura, N., Yoshioka, M., and Fukuda, K. (2009) Molecular mechanisms underlying the onset of degenerative aortic valve disease. J. Mol. Med. 87, 17-24.

26. Gittenberger-de Groot, A.C., Bartelings, M.M., DeRuiter, M.C., and Poelmann, R.E. (2005) Basics of cardiac development for the understanding of congenital heart malformations. Pediatr. Res. 57, 169-176.

27. Lie-Venema, H., van den Akker, N.M., Bax, N.A., Winter, E.M., Maas, S., Kekarainen, T., Hoeben, R.C., DeRuiter, M.C., Poelmann, R.E., and Gittenberger-de Groot, A.C. (2007) Origin, fate, and function of epicardium-derived cells (EPDCs) in normal and abnormal cardiac development. TheScientificWorldJOURNAL 7, 1777-1798.

28. Hinton, R.B. and Yutzey, K.E. (2011) Heart valve structure and function in development and disease. Annu. Rev. Physiol. 73, 29-46.

29. Delaughter, D.M., Saint-Jean, L., Baldwin, H.S., and Barnett, J.V. (2011) What chick and mouse models have taught us about the role of the endocardium in congenital heart disease. Birth Defects Res. A Clin. Mol. Teratol. 91, 511525.

30. Mercado-Pimentel, M.E. and Runyan, R.B. (2007) Multiple transforming growth factor-beta isoforms and receptors function during epithelial-mesenchymal cell transformation in the embryonic heart. Cells Tissues Organs 185, 146156.

31. Butcher, J.T. and Markwald, R.R. (2007) Valvulogenesis: the moving target. Philos. Trans. R. Soc. Lond. B Biol. Sci. 362, 1489-1503.

32. Kruithof, B.P., Krawitz, S.A., and Gaussin, V. (2007) Atrioventricular valve development during late embryonic and postnatal stages involves condensation and extracellular matrix remodeling. Dev. Biol. 302, $208-217$.

33. Huang, X.F. and Chai, Y. (2010) TGF-ss signalling and tooth development. Chin. J. Dent. Res. 13, 7-15.

34. Van Hemelrijk, C., Renard, M., and Loeys, B. (2010) The Loeys-Dietz syndrome: an update for the clinician. Curr. Opin. Cardiol. 25, 546-551.

35. Massague, J. (1998) TGF-beta signal transduction. Annu. Rev. Biochem. 67, 753-791.

36. Bragdon, B., Moseychuk, O., Saldanha, S., King, D., Julian, J., and Nohe, A. (2011) Bone morphogenetic proteins: a critical review. Cell Signal. 23, 609-620.

37. Litvin, J., Blagg, A., Mu, A., Matiwala, S., Montgomery, M., Berretta, R., Houser, S., and Margulies, K. (2006) Periostin and periostin-like factor in the human heart: possible therapeutic targets. Cardiovasc. Pathol. 15, $24-32$.

38. Hamilton, D.W. (2008) Functional role of periostin in development and wound repair: implications for connective tissue disease. J. Cell Commun. Signal. 2, 9-17.

39. Norris, R.A., Moreno-Rodriguez, R.A., Sugi, Y., Hoffman, S., Amos, J., Hart, M.M., Potts, J.D., Goodwin, R.L., and Markwald, R.R. (2008) Periostin regulates atrioventricular valve maturation. Dev. Biol. 316, 200-213.

40. Levay, A.K., Peacock, J.D., Lu, Y., Koch, M., Hinton, R.B., Jr., Kadler, K.E., and Lincoln, J. (2008) Scleraxis is required for cell lineage differentiation and extracellular matrix remodeling during murine heart valve formation in vivo. Circ. Res. 103, 948-956.

41. Sanford, L.P., Ormsby, I., Gittenberger-de Groot, A.C., Sariola, H., Friedman, R., Boivin, G.P., Cardell, E.L., and Doetschman, T. (1997) TGFbeta2 knockout mice have multiple developmental defects that are non-overlapping with other TGFbeta knockout phenotypes. Development 124, 2659-2670.

42. Azhar, M., Runyan, R.B., Gard, C., Sanford, L.P., Miller, M.L., Andringa, A., Pawlowski, S., Rajan, S., and Doetschman, T. (2009) Ligand-specific function of transforming growth factor beta in epithelial-mesenchymal transition in heart development. Dev. Dyn. 238, 431-442.

43. Azhar, M., Brown, K., Gard, C., Chen, H.D.R., Rajan, S., Elliott, D.A., Stevens, M.V., Camenisch, T.D., Conway, S.J., and Doetschman, T. (2011) Transforming growth factor beta2 is required for valve remodeling during heart development. Dev. Dyn., in press.

44. van de Laar, I.M., Oldenburg, R.A., Pals, G., Roos-Hesselink, J.W., de Graaf, B.M., Verhagen, J.M., Hoedemaekers, Y.M., Willemsen, R., Severijnen, L.A., Venselaar, H., Vriend, G., Pattynama, P.M., Collee, M., Majoor-Krakauer, D., Poldermans, D., Frohn-Mulder, I.M., Micha, D., Timmermans, J., Hilhorst-Hofstee, Y., Bierma-Zeinstra, S.M., Willems, P.J., Kros, J.M., Oei, E.H., Oostra, B.A., Wessels, M.W., and Bertoli-Avella, A.M. (2011) Mutations in SMAD3 cause a syndromic form of aortic aneurysms and dissections with early-onset osteoarthritis. Nat. Genet. 43, 121-126. 
45. Andrabi, S., Bekheirnia, M.R., Robbins-Furman, P., Lewis, R.A., Prior, T.W., and Potocki, L. (2011) SMAD4 mutation segregating in a family with juvenile polyposis, aortopathy, and mitral valve dysfunction. Am. J. Med. Genet. A 155A, 1165-1169.

46. Matt, P., Schoenhoff, F., Habashi, J., Holm, T., van Erp, C., Loch, D., Carlson, O.D., Griswold, B.F., Fu, Q., De Backer, J., Loeys, B., Huso, D.L., McDonnell, N.B., Van Eyk, J.E., Dietz, H.C.; GenTAC Consortium (2009) Circulating transforming growth factor- $\{$ beta $\}$ in Marfan syndrome. Circulation 120, 526-532

47. Loeys, B.L., Chen, J., Neptune, E.R., Judge, D.P., Podowski, M., Holm, T., Meyers, J., Leitch, C.C., Katsanis, N., Sharifi, N., Xu, F.L., Myers, L.A., Spevak, P.J., Cameron, D.E., De Backer, J., Hellemans, J., Chen, Y., Davis, E.C., Webb, C.L., Kress, W., Coucke, P., Rifkin, D.B., De Paepe, A.M., and Dietz, H.C. (2005) A syndrome of altered cardiovascular, craniofacial, neurocognitive and skeletal development caused by mutations in TGFBR1 or TGFBR2. Nat. Genet. 37, 275-281.

48. Kim, L., Kim, D.K., Yang, W.I., Shin, D.H., Jung, I.M., Park, H.K., and Chang, B.C. (2008) Overexpression of transforming growth factor-beta 1 in the valvular fibrosis of chronic rheumatic heart disease. J. Korean Med. Sci. 23, 41-48.

49. Kaden, J.J., Bickelhaupt, S., Grobholz, R., Vahl, C.F., Hagl, S., Brueckmann, M., Haase, K.K., Dempfle, C.E., and Borggrefe, M. (2004) Expression of bone sialoprotein and bone morphogenetic protein-2 in calcific aortic stenosis. $J$. Heart Valve Dis. 13, 560-566.

50. Snider, P., Standley, K.N., Wang, J., Azhar, M., Doetschman, T., and Conway, S.J. (2009) Origin of cardiac fibroblasts and the role of periostin. Circ. Res. 105, 934-947.

51. Conway, S.J. and Molkentin, J.D. (2008) Periostin as a heterofunctional regulator of cardiac development and disease. Curr. Genomics 9, 548-555.

52. Gillan, L., Matei, D., Fishman, D.A., Gerbin, C.S., Karlan, B.Y., and Chang, D.D. (2002) Periostin secreted by epithelial ovarian carcinoma is a ligand for alpha(V)beta(3) and alpha(V)beta(5) integrins and promotes cell motility. Cancer Res. 62, 5358-5364.

53. Baril, P., Gangeswaran, R., Mahon, P.C., Caulee, K., Kocher, H.M., Harada, T., Zhu, M., Kalthoff, H., CrnogoracJurcevic, T., and Lemoine, N.R. (2007) Periostin promotes invasiveness and resistance of pancreatic cancer cells to hypoxia-induced cell death: role of the beta4 integrin and the PI3k pathway. Oncogene 26, 2082-2094.

54. Ruan, K., Bao, S., and Ouyang, G. (2009) The multifaceted role of periostin in tumorigenesis. Cell. Mol. Life Sci. 66, 2219-2230.

55. Kruzynska-Frejtag, A., Machnicki, M., Rogers, R., Markwald, R.R., and Conway, S.J. (2001) Periostin (an osteoblast-specific factor) is expressed within the embryonic mouse heart during valve formation. Mech. Dev. 103, 183-188.

56. Erkan, M., Kleeff, J., Gorbachevski, A., Reiser, C., Mitkus, T., Esposito, I., Giese, T., Buchler, M.W., Giese, N.A., and Friess, H. (2007) Periostin creates a tumor-supportive microenvironment in the pancreas by sustaining fibrogenic stellate cell activity. Gastroenterology 132, 1447-1464.

57. Kim, C.J., Yoshioka, N., Tambe, Y., Kushima, R., Okada, Y., and Inoue, H. (2005) Periostin is down-regulated in high grade human bladder cancers and suppresses in vitro cell invasiveness and in vivo metastasis of cancer cells. Int. J. Cancer 117, 51-58.

58. Meulmeester, E. and ten Dijke, P. (2011) The dynamic roles of TGF-beta in cancer. J. Pathol. 223, $205-218$.

59. Massague, J. (2008) TGFbeta in Cancer. Cell 134, 215-230.

60. Blanco Calvo, M., Bolós Fernández, V., Medina Villaamil, V., Aparicio Gallego, G., Díaz Prado, S., and Grande Pulido, E. (2009) Biology of BMP signalling and cancer. Clin. Transl. Oncol. 11, 126-137.

61. Takeshita, S., Kikuno, R., Tezuka, K., and Amann, E. (1993) Osteoblast-specific factor 2: cloning of a putative bone adhesion protein with homology with the insect protein fasciclin I. Biochem. J. 294, 271-278.

62. Rios, H., Koushik, S.V., Wang, H., Wang, J., Zhou, H.M., Lindsley, A., Rogers, R., Chen, Z., Maeda, M., Kruzynska-Frejtag, A., Feng, J.Q., and Conway, S.J. (2005) Periostin null mice exhibit dwarfism, incisor enamel defects, and an early-onset periodontal disease-like phenotype. Mol. Cell. Biol. 25, 11131-11144.

63. Kashima, T.G., Nishiyama, T., Shimazu, K., Shimazaki, M., Kii, I., Grigoriadis, A.E., Fukayama, M., and Kudo, A. (2009) Periostin, a novel marker of intramembranous ossification, is expressed in fibrous dysplasia and in c-Fosoverexpressing bone lesions. Hum. Pathol. 40, 226-237.

64. Serra, R. and Chang, C. (2003) TGF-beta signaling in human skeletal and patterning disorders. Birth Defects Res. C Embryo Today 69, 333-351.

65. Lincoln, J., Lange, A.W., and Yutzey, K.E. (2006) Hearts and bones: shared regulatory mechanisms in heart valve, cartilage, tendon, and bone development. Dev. Biol. 294, 292-302.

66. Chakraborty, S., Cheek, J., Sakthivel, B., Aronow, B.J., and Yutzey, K.E. (2008) Shared gene expression profiles in developing heart valves and osteoblast progenitor cells. Physiol. Genomics. 35, 75-85.

67. Tkatchenko, T.V., Moreno-Rodriguez, R.A., Conway, S.J., Molkentin, J.D., Markwald, R.R., and Tkatchenko, A.V. (2009) Lack of periostin leads to suppression of Notch1 signaling and calcific aortic valve disease. Physiol. Genomics 39, 160-168.

68. Annes, J.P., Munger, J.S., and Rifkin, D.B. (2003) Making sense of latent TGFbeta activation. J. Cell Sci. 116, 217224. 
69. Ramirez, F. and Rifkin, D.B. (2009) Extracellular microfibrils: contextual platforms for TGFbeta and BMP signaling. Curr. Opin. Cell Biol. 21, 616-622.

70. Kang, J.S., Liu, C., and Derynck, R. (2009) New regulatory mechanisms of TGF-beta receptor function. Trends Cell Biol. 19, 385-394.

71. Brown, C.B., Boyer, A.S., Runyan, R.B., and Barnett, J.V. (1999) Requirement of type III TGF-beta receptor for endocardial cell transformation in the heart. Science 283, 2080-2082.

72. ten Dijke, P., Goumans, M.J., and Pardali, E. (2008) Endoglin in angiogenesis and vascular diseases. Angiogenesis 11, 79-89.

73. Goumans, M.J., Liu, Z., and ten Dijke, P. (2008) TGF-beta signaling in vascular biology and dysfunction. Cell Res. 19, 116-127.

74. Pece-Barbara, N., Vera, S., Kathirkamathamby, K., Liebner, S., Di Guglielmo, G.M., Dejana, E., Wrana, J.L., and Letarte, M. (2005) Endoglin null endothelial cells proliferate faster and are more responsive to transforming growth factor beta1 with higher affinity receptors and an activated Alk1 pathway. J. Biol. Chem. 280, 27800-27808.

75. Kim, Y., Kugler, M.C., Wei, Y., Kim, K.K., Li, X., Brumwell, A.N., and Chapman, H.A. (2009) Integrin alpha3beta1-dependent beta-catenin phosphorylation links epithelial Smad signaling to cell contacts. J. Cell Biol. 184, 309-322.

76. Li, P., Pashmforoush, M., and Sucov, H.M. (2010) Retinoic acid regulates differentiation of the secondary heart field and TGFbeta-mediated outflow tract septation. Dev. Cell 18, 480-485.

77. Hoover, L.L., Burton, E.G., Brooks, B.A., and Kubalak, S.W. (2008) The expanding role for retinoid signaling in heart development. TheScientificWorldJOURNAL 8, 194-211.

78. Miyazono, K., Kamiya, Y., and Morikawa, M. (2010) Bone morphogenetic protein receptors and signal transduction. J. Biochem. 147, 35-51.

79. Goto, K., Kamiya, Y., Imamura, T., Miyazono, K., and Miyazawa, K. (2007) Selective inhibitory effects of Smad6 on bone morphogenetic protein type I receptors. J. Biol. Chem. 282, 20603-20611.

80. Tang, S., Snider, P., Firulli, A.B., and Conway, S.J. (2010) Trigenic neural crest-restricted Smad7 over-expression results in congenital craniofacial and cardiovascular defects. Dev. Biol. 344, 233-247.

81. Kirkbride, K.C., Townsend, T.A., Bruinsma, M.W., Barnett, J.V., and Blobe, G.C. (2008) Bone morphogenetic proteins signal through the transforming growth factor-beta type III receptor. J. Biol. Chem. 283, 7628-7637.

82. Townsend, T.A., Robinson, J.Y., Deig, C.R., Hill, C.R., Misfeldt, A., Blobe, G.C., and Barnett, J.V. (2011) BMP-2 and TGFbeta2 shared pathways regulate endocardial cell transformation. Cells Tissues Organs 194, 1-12.

83. Daly, A.C., Randall, R.A., and Hill, C.S. (2008) Transforming growth factor beta-induced Smad1/5 phosphorylation in epithelial cells is mediated by novel receptor complexes and is essential for anchorage-independent growth. Mol. Cell. Biol. 28, 6889-6902.

84. Molin, D.G., Bartram, U., Van der Heiden, K., Van Iperen, L., Speer, C.P., Hierck, B.P., Poelmann, R.E., and Gittenberger-de-Groot, A.C. (2003) Expression patterns of Tgfbeta1-3 associate with myocardialisation of the outflow tract and the development of the epicardium and the fibrous heart skeleton. Dev. Dyn. 227, 431-444.

85. Camenisch, T.D., Molin, D.G., Person, A., Runyan, R.B., Gittenberger-de Groot, A.C., McDonald, J.A., and Klewer, S.E. (2002) Temporal and distinct TGFbeta ligand requirements during mouse and avian endocardial cushion morphogenesis. Dev. Biol. 248, 170-181.

86. Akhurst, R.J., Lehnert, S.A., Faissner, A., and Duffie, E. (1990) TGF beta in murine morphogenetic processes: the early embryo and cardiogenesis. Development 108, 645-656.

87. Dickson, M.C., Slager, H.G., Duffie, E., Mummery, C.L., and Akhurst, R.J. (1993) RNA and protein localisations of TGF beta 2 in the early mouse embryo suggest an involvement in cardiac development. Development 117, 625-639.

88. Millan, F.A., Denhez, F., Kondaiah, P., and Akhurst, R.J. (1991) Embryonic gene expression patterns of TGF beta 1, beta 2 and beta 3 suggest different developmental functions in vivo. Development 111, 131-143.

89. Vrljicak, P., Chang, A.C., Morozova, O., Wederell, E.D., Niessen, K., Marra, M.A., Karsan, A., and Hoodless, P.A. (2010) Genomic analysis distinguishes phases of early development of the mouse atrio-ventricular canal. Physiol. Genomics 40, 150-157.

90. Beffagna, G., Occhi, G., Nava, A., Vitiello, L., Ditadi, A., Basso, C., Bauce, B., Carraro, G., Thiene, G., Towbin, J.A., Danieli, G.A., and Rampazzo, A. (2005) Regulatory mutations in transforming growth factor-beta3 gene cause arrhythmogenic right ventricular cardiomyopathy type 1. Cardiovasc. Res. 65, 366-373.

91. Hu, B.C., Li, L., Sun, R.H., Gao, P.J., Zhu, D.L., Wang, J.G., and Chu, S.L. (2010) The association between transforming growth factor beta3 polymorphisms and left ventricular structure in hypertensive subjects. Clin. Chim. Acta 411, 558-562.

92. Teekakirikul, P., Eminaga, S., Toka, O., Alcalai, R., Wang, L., Wakimoto, H., Nayor, M., Konno, T., Gorham, J.M., Wolf, C.M., Kim, J.B., Schmitt, J.P., Molkentin, J.D., Norris, R.A., Tager, A.M., Hoffman, S.R., Markwald, R.R., Seidman, C.E., and Seidman, J.G. (2010) Cardiac fibrosis in mice with hypertrophic cardiomyopathy is mediated by non-myocyte proliferation and requires Tgf-beta. J. Clin. Invest. 120, 3520-3529.

93. Yang, J.H., Wylie-Sears, J., and Bischoff, J. (2008) Opposing actions of Notch1 and VEGF in post-natal cardiac valve endothelial cells. Biochem. Biophys. Res. Commun. 374, 512-516. 
94. Shull, M.M., Ormsby, I., Kier, A.B., Pawlowski, S., Diebold, R.J., Yin, M., Allen, R., Sidman, C., Proetzel, G., Calvin, D., and Doetschman, T. (1992) Targeted disruption of the mouse transforming growth factor-beta 1 gene results in multifocal inflammatory disease. Nature 359, 693-699.

95. Proetzel, G., Pawlowski, S.A., Wiles, M.V., Yin, M., Boivin, G.P., Howles, P.N., Ding, J., Ferguson, M.W., and Doetschman, T. (1995) Transforming growth factor-beta 3 is required for secondary palate fusion. Nat. Genet. 11, 409-414.

96. Bartram, U., Molin, D.G., Wisse, L.J., Mohamad, A., Sanford, L.P., Doetschman, T., Speer, C.P., Poelmann, R.E., and Gittenberger-de Groot, A.C. (2001) Double-outlet right ventricle and overriding tricuspid valve reflect disturbances of looping, myocardialization, endocardial cushion differentiation, and apoptosis in Tgfb2 knockout mice. Circulation 103, 2745-2752.

97. Wang, J., Greene, S.B., and Martin, J.F. (2011) BMP signaling in congenital heart disease: new developments and future directions. Birth Defects Res. A Clin. Mol. Teratol. 91, 441-448.

98. Ma, L., Lu, M.F., Schwartz, R.J., and Martin, J.F. (2005) Bmp2 is essential for cardiac cushion epithelialmesenchymal transition and myocardial patterning. Development 132, 5601-5611.

99. Delot, E.C. (2003) Control of endocardial cushion and cardiac valve maturation by BMP signaling pathways. Mol. Genet. Metab. 80, 27-35.

100. Liu, W., Selever, J., Wang, D., Lu, M.F., Moses, K.A., Schwartz, R.J., and Martin, J.F. (2004) Bmp4 signaling is required for outflow-tract septation and branchial-arch artery remodeling. Proc. Natl. Acad. Sci. U. S. A. 101, 44894494.

101. Kim, R.Y., Robertson, E.J., and Solloway, M.J. (2001) Bmp6 and Bmp7 are required for cushion formation and septation in the developing mouse heart. Dev. Biol. 235, 449-466.

102. Sugi, Y., Yamamura, H., Okagawa, H., and Markwald, R.R. (2004) Bone morphogenetic protein-2 can mediate myocardial regulation of atrioventricular cushion mesenchymal cell formation in mice. Dev. Biol. 269, 505-518.

103. Kajbaf, S., Veinot, J.P., Ha, A., and Zimmerman, D. (2005) Comparison of surgically removed cardiac valves of patients with ESRD with those of the general population. Am. J. Kidney Dis. 46, 86-93.

104. Uchimura, T., Komatsu, Y., Tanaka, M., McCann, K.L., and Mishina, Y. (2009) Bmp2 and Bmp4 genetically interact to support multiple aspects of mouse development including functional heart development. Genesis 47, 374-384.

105. Delot, E.C., Bahamonde, M.E., Zhao, M., and Lyons, K.M. (2003) BMP signaling is required for septation of the outflow tract of the mammalian heart. Development 130, 209-220.

106. Jiao, K., Kulessa, H., Tompkins, K., Zhou, Y., Batts, L., Baldwin, H.S., and Hogan, B.L. (2003) An essential role of Bmp4 in the atrioventricular septation of the mouse heart. Genes Dev. 17, 2362-2367.

107. Beppu, H., Malhotra, R., Beppu, Y., Lepore, J.J., Parmacek, M.S., and Bloch, K.D. (2009) BMP type II receptor regulates positioning of outflow tract and remodeling of atrioventricular cushion during cardiogenesis. Dev. Biol. 331, 167-175.

108. McCulley, D.J., Kang, J.O., Martin, J.F., and Black, B.L. (2008) BMP4 is required in the anterior heart field and its derivatives for endocardial cushion remodeling, outflow tract septation, and semilunar valve development. Dev. Dyn. 237, 3200-3209.

109. Choi, M., Stottmann, R.W., Yang, Y.P., Meyers, E.N., and Klingensmith, J. (2007) The bone morphogenetic protein antagonist noggin regulates mammalian cardiac morphogenesis. Circ. Res. 100, 220-228.

110. Galvin, K.M., Donovan, M.J., Lynch, C.A., Meyer, R.I., Paul, R.J., Lorenz, J.N., Fairchild-Huntress, V., Dixon, K.L., Dunmore, J.H., Gimbrone, M.A., Jr., Falb, D., and Huszar, D. (2000) A role for smad6 in development and homeostasis of the cardiovascular system. Nat. Genet. 24, 171-174.

111. Rivera-Feliciano, J. and Tabin, C.J. (2006) Bmp2 instructs cardiac progenitors to form the heart-valve-inducing field. Dev. Biol. 295, 580-588.

112. Bharathy, S., Xie, W., Yingling, J.M., and Reiss, M. (2008) Cancer-associated transforming growth factor beta type II receptor gene mutant causes activation of bone morphogenic protein-Smads and invasive phenotype. Cancer Res. 68 , 1656-1666.

113. Wang, J., Sridurongrit, S., Dudas, M., Thomas, P., Nagy, A., Schneider, M.D., Epstein, J.A., and Kaartinen, V. (2005) Atrioventricular cushion transformation is mediated by ALK2 in the developing mouse heart. Dev. Biol. 286, 299-310.

114. Gaussin, V., Morley, G.E., Cox, L., Zwijsen, A., Vance, K.M., Emile, L., Tian, Y., Liu, J., Hong, C., Myers, D., Conway, S.J., Depre, C., Mishina, Y., Behringer, R.R., Hanks, M.C., Schneider, M.D., Huylebroeck, D., Fishman, G.I., Burch, J.B., and Vatner, S.F. (2005) Alk3/Bmprla receptor is required for development of the atrioventricular canal into valves and annulus fibrosus. Circ. Res. 97, 219-226.

115. Barnett, J.V. and Desgrosellier, J.S. (2003) Early events in valvulogenesis: a signaling perspective. Birth Defects Res. C Embryo Today 69, 58-72.

116. Lindsley, A., Snider, P., Zhou, H., Rogers, R., Wang, J., Olaopa, M., Kruzynska-Frejtag, A., Koushik, S.V., Lilly, B., Burch, J.B., Firulli, A.B., and Conway, S.J. (2007) Identification and characterization of a novel Schwann and outflow tract endocardial cushion lineage-restricted periostin enhancer. Dev. Biol. 307, 340-355.

117. Lee, K.H., Evans, S., Ruan, T.Y., and Lassar, A.B. (2004) SMAD-mediated modulation of YY1 activity regulates the BMP response and cardiac-specific expression of a GATA4/5/6-dependent chick Nkx2.5 enhancer. Development 131, 4709-4723. 
118. Kurisaki, K., Kurisaki, A., Valcourt, U., Terentiev, A.A., Pardali, K., ten Dijke, P., Heldin, C.H., Ericsson, J., and Moustakas, A. (2003) Nuclear factor YY1 inhibits transforming growth factor beta- and bone morphogenetic proteininduced cell differentiation. Mol. Cell. Biol. 23, 4494-4510.

119. Horiuchi, K., Amizuka, N., Takeshita, S., Takamatsu, H., Katsuura, M., Ozawa, H., Toyama, Y., Bonewald, L.F., and Kudo, A. (1999) Identification and characterization of a novel protein, periostin, with restricted expression to periosteum and periodontal ligament and increased expression by transforming growth factor beta. J. Bone Miner. Res. 14, 1239-1249.

120. Zhou, H.M., Wang, J., Elliott, C., Wen, W., Hamilton, D.W., and Conway, S.J. (2010) Spatiotemporal expression of periostin during skin development and incisional wound healing: lessons for human fibrotic scar formation. J. Cell Commun. Signal. 4, 99-107.

121. Norris, R.A., Potts, J.D., Yost, M.J., Junor, L., Brooks, T., Tan, H., Hoffman, S., Hart, M.M., Kern, M.J., Damon, B., Markwald, R.R., and Goodwin, R.L. (2009) Periostin promotes a fibroblastic lineage pathway in atrioventricular valve progenitor cells. Dev. Dyn. 238, 1052-1063.

122. Li, G., Oparil, S., Sanders, J.M., Zhang, L., Dai, M., Chen, L.B., Conway, S.J., McNamara, C.A., and Sarembock, I.J. (2006) Phosphatidylinositol-3-kinase signaling mediates vascular smooth muscle cell expression of periostin in vivo and in vitro. Atherosclerosis 188, 292-300.

123. Snider, P., Olaopa, M., Firulli, A.B., and Conway, S.J. (2007) Cardiovascular development and the colonizing cardiac neural crest lineage. TheScientificWorldJOURNAL 7, 1090-1113.

124. Jiang, X., Rowitch, D.H., Soriano, P., McMahon, A.P., and Sucov, H.M. (2000) Fate of the mammalian cardiac neural crest. Development 127, 1607-1616.

125. Molin, D.G., Poelmann, R.E., DeRuiter, M.C., Azhar, M., Doetschman, T., and Gittenberger-de Groot, A.C. (2004) Transforming growth factor beta-SMAD2 signaling regulates aortic arch innervation and development. Circ. Res. 95, 1109-1117.

126. Cohn, R.D., van Erp, C., Habashi, J.P., Soleimani, A.A., Klein, E.C., Lisi, M.T., Gamradt, M., ap Rhys, C.M., Holm, T.M., Loeys, B.L., Ramirez, F., Judge, D.P., Ward, C.W., and Dietz, H.C. (2007) Angiotensin II type 1 receptor blockade attenuates TGF-beta-induced failure of muscle regeneration in multiple myopathic states. Nat. Med. 13, 204-210.

127. Walker, G.A., Masters, K.S., Shah, D.N., Anseth, K.S., and Leinwand, L.A. (2004) Valvular myofibroblast activation by transforming growth factor-beta: implications for pathological extracellular matrix remodeling in heart valve disease. Circ. Res. 95, 253-260.

128. Lie-Venema, H., Eralp, I., Markwald, R.R., van den Akker, N.M., Wijffels, M.C., Kolditz, D.P., van der Laarse, A., Schalij, M.J., Poelmann, R.E., Bogers, A.J., and Gittenberger-de Groot, A.C. (2008) Periostin expression by epicardium-derived cells is involved in the development of the atrioventricular valves and fibrous heart skeleton. Differentiation 76, 809-819.

129. Ji, X., Chen, D., Xu, C., Harris, S.E., Mundy, G.R., and Yoneda, T. (2000) Patterns of gene expression associated with BMP-2-induced osteoblast and adipocyte differentiation of mesenchymal progenitor cell 3T3-F442A. J. Bone Miner. Metab. 18, 132-139.

130. Inai, K., Norris, R.A., Hoffman, S., Markwald, R.R., and Sugi, Y. (2008) BMP-2 induces cell migration and periostin expression during atrioventricular valvulogenesis. Dev. Biol. 315, 383-396.

\section{This article should be cited as follows:}

Conway, S.J., Doetschman, T., and Azhar, M. (2011) The inter-relationship of periostin, TGF $\beta$, and BMP in heart valve development and valvular heart diseases. TheScientificWorldJOURNAL: TSW Development \& Embryology 11, $1509-1524$. DOI 10.1100/tsw.2011.132. 


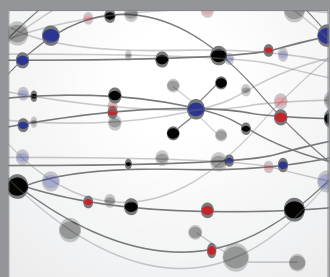

The Scientific World Journal
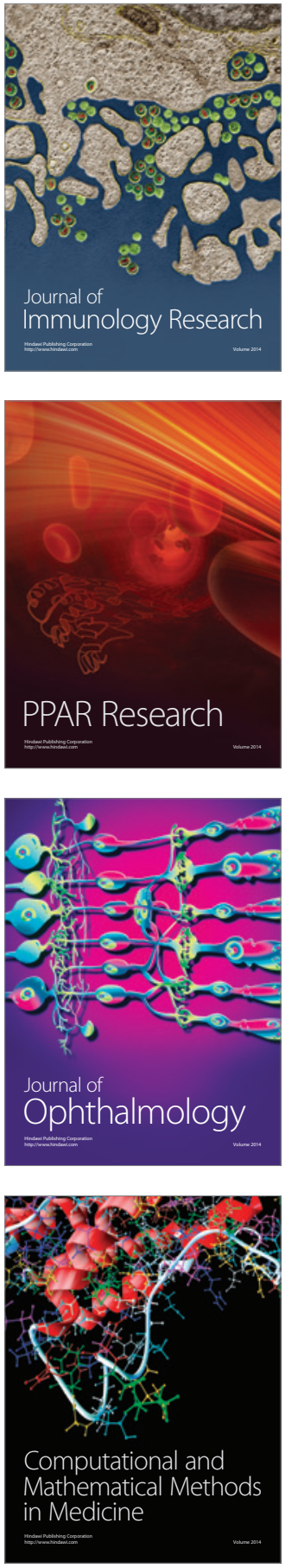

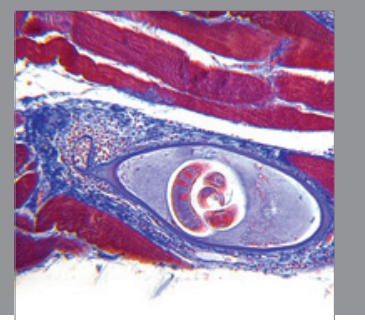

Gastroenterology

Research and Practice
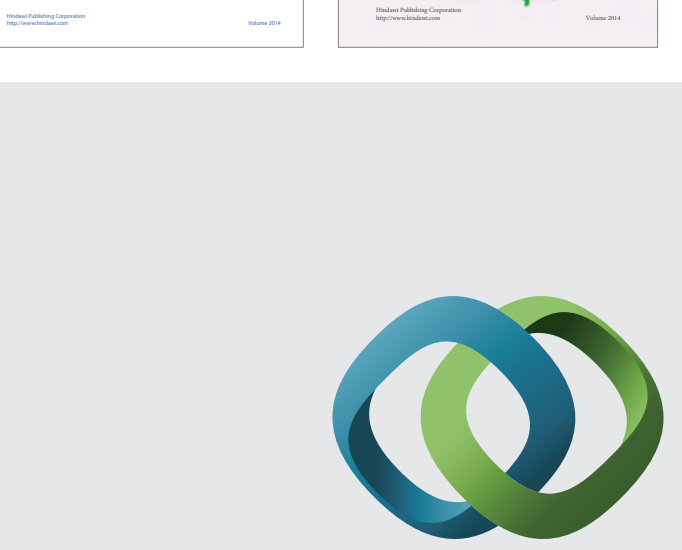

\section{Hindawi}

Submit your manuscripts at

http://www.hindawi.com
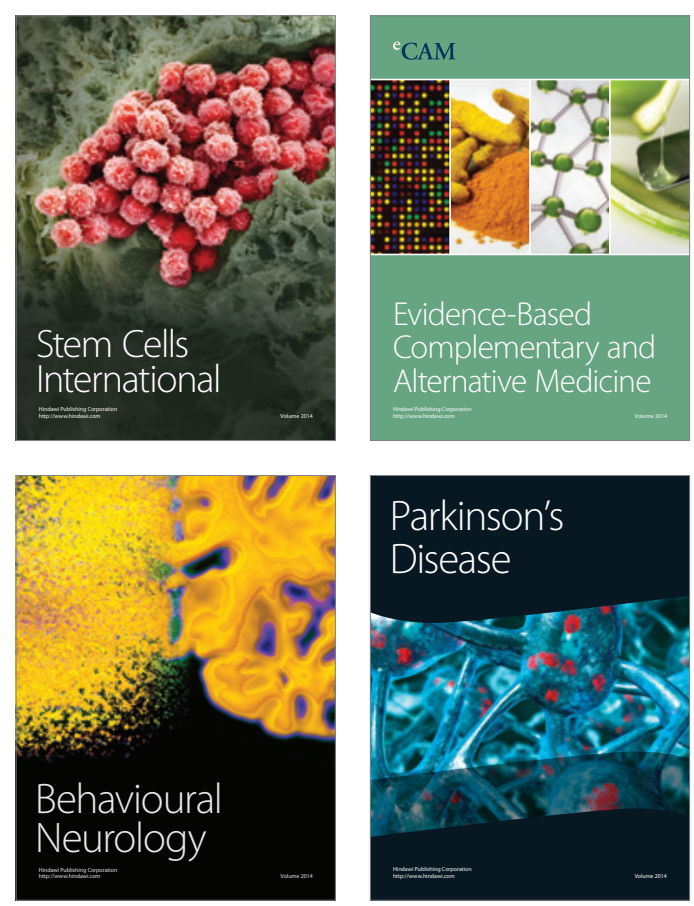

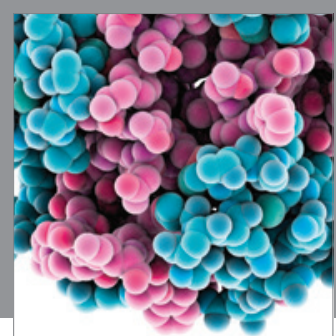

Journal of
Diabetes Research

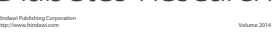

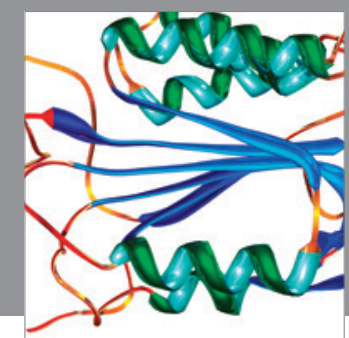

Disease Markers
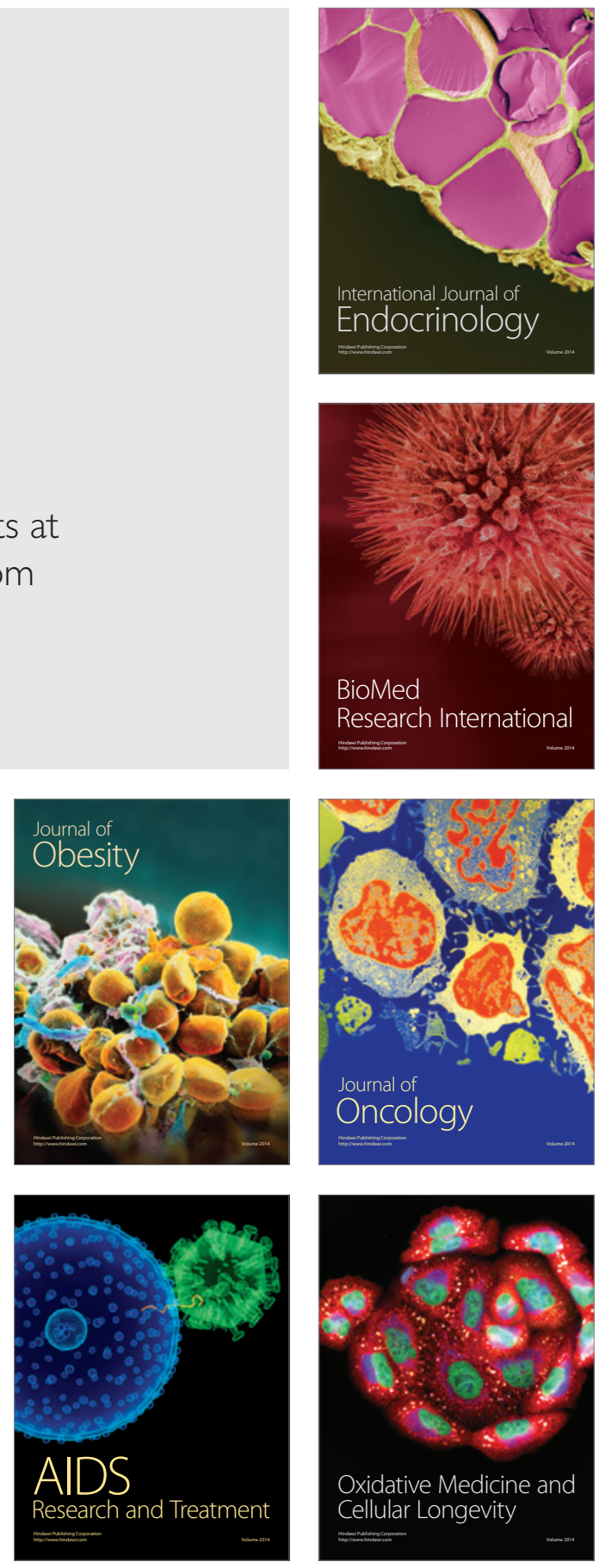